\title{
ANALISIS RETURN SAHAM PADA PERUSAHAAN PERTAMBANGAN BATUBARA DI BURSA EFEK INDONESIA
}

\author{
Nurhudawi \\ Univesitas Islam Negeri Sumatera Utara \\ E-mail:nurhudawilubis@gmail.com
}

\section{Saleh Sitompul}

Institut Teknologi Manajemen Internasional Program Studi Akuntansi

E-mail: jokowiahmad44@gmail.com

\begin{abstract}
ABSTRAK
Penelitian ini bertujuan untuk menganalisis return saham pada perusahaan pertambangan batubara di Bursa Efek Indonesia. Perusahaan pertambangan membutuhkan modal yang sangat besar dalam mengeksplorasi sumber daya alam dalam mengembangkan pertambangan. Variabel independen yang digunakan dalam penelitian ini adalah current ratio, return on equity, net profit margin, firm size. Jenis data yang digunakan dalam penelitian ini adalah data kuantitatif, yakni data yang berwujud angka-angka. Sumber data sekunder dari penelitian ini adalah laporan keuangan perusahaan. Data sekunder ini diperoleh dari website resmi Bursa Efek Indonesia yaitu www.idx.co.id. Hasil penelitian ini menunjukkan bahwa variabel curent ratio memiliki pengaruh negatif dan tidak signifikan terhadap variabel return saham. Return on equity berpengaruh positif namun tidak signifikan terhadap variabel return saham. Variabel net profit margin memiliki pengaruh negatif dan tidak signifikan terhadap variabel return saham. Variabel firm size berpengaruh negatif dan signifikan terhadap variabel return saham. Variabel curent ratio, return on equity, net profit margin, dan firm size secara simultan berpengaruh signifikan terhadap variabel return saham. Penelitian ini memberikan rekomendasi bagi manajer keuangan perusahaan untuk dapat menentukan kebijakan peningkatan net profit margin untuk menarik meningkatkan kesejahteraan bagi investor sehingga investor pun dapat menetapkan keputusan investasi yang tepat.
\end{abstract}

Kata Kunci: Return Saham; Current Ratio; Return On Equity; Net Profit Margin; Firm Size 


\section{PENDAHULUAN}

Pasar modal dibentuk untuk menjalankan fungsi ekonomi dan keuangan dalam sistem perekonomian suatu negara. Dilihat dari perkembangannya, jumlah perusahaan yang menjual sahamnya di pasar modal semakin meningkat. Dalam kaitannya dengan investasi saham, investor memilih saham perusahaan yang layak untuk dipilih berdasarkan kriteria tertentu. Investor yang rasional akan mempertimbangkan dua hal yaitu pendapatan yang diharapkan (expected return) dan risiko (risk) yang terkandung dalam alternatif investasi yang dilakukan. Semakin baik kinerja suatu perusahaan maka semakin kecil kemungkinan risiko investasi yang akan ditanggung dan semakin besar kemungkinan return yang akan diperoleh. Ini akan mengakibatkan semakin banyak investor yang akan berinvestasi pada perusahaan tersebut.

Investasi adalah komitmen atas sejumlah dana atau sumber daya lainnya yang dilakukan pada saat ini, dengan tujuan memperoleh sejumlah keuntungan di masa datang. Pihak-pihak yang melakukan kegiatan investasi disebut investor. Investor pada umumnya bisa digolongkan menjadi dua, yaitu investor individual (individual/ retail investors) dan investor institusional (institutional investors). Investor individual terdiri dari individu-individu yang melakukan aktivitas investasi, sedangkan investor institusional biasanya terdiri dari perusahaan- perusahaan asuransi, lembaga penyimpanan dana (bank dan lembaga simpan pinjam), lembaga dana pensiun, maupun perusahaan investasi (Tandelilin, 2010)

Perusahaan pertambangan membutuhkan modal yang sangat besar dalam mengeksplorasi sumber daya alam dalam mengembangkan pertambangan. Untuk itu, perusahaan pertambangan banyak masuk ke pasar modal untuk menyerap investasi dan untuk memperkuat posisi keuangannya. Pasar modal memiliki peran yang besar bagi perekonomian suatu negara karena pasar modal menjalankan dua fungsi sekaligus, yaitu fungsi ekonomi dan fungsi keuangan. Investasi dalam saham tergantung pada fluktuasi harga saham di bursa, ketidakstabilan tingkat bunga, ketidakstabilan pasar dan juga kinerja keuangan perusahaan tersebut. Untuk itu dalam melakukan investasi dalam bentuk saham, investor harus melakukan analisis terhadap faktor yang dapat mempengaruhi kondisi perusahaan.

Harga batubara mengalami penurunan dari tahun 2012 sampai 2016. Dari tahun 2017 harga batubara sudah menunjukkan peningkatan yang didukung oleh kenaikan permintaan dari negara China. Dapat dilihat juga harga saham PT Indo Tambangraya Megah 
(ITMG) mengalami fluktuasi. Dari tahun 2012 harga saham ITMG menunjukan tren menurun sampai pertengahan 2016. Dari pertengahan tahun 2016 harga saham ITMG mulai mengalami peningkatan sampai tahun 2018.

Tujuan utama seseorang berinvestasi pada sebuah perusahaan adalah mendapatkan pengembalian atas investasinya secara maksimal dengan risiko minimal. Tinggi rendahnya return yang diterima oleh investor dapat menggambarkan keadaan suatu perusahaan apakah mendapatkan keuntungan atau megalami kerugian. Semakin tinggi return yang didapatkan investor berarti bahwa perusahaan berhasil menciptakan nilai tambah bagi perusahaan itu sendiri maupun bagi kemakmuran pemegang saham.

Return Saham adalah hasil yang diperoleh dari suatu investasi yang terdiri dari dividen dan capital gain (loss). Dividen adalah pembagian laba kepada pemegang saham, sedangkan capital gain merupakan selisih dari harga beli dengan harga jual suatu surat berharga. Capital gain merupakan kenaikan dari harga suatu saham dan capital loss merupakan punurunan harga suatu saham. Meningkatnya laba atau keuntungan perusahaan dari tahun ke tahun akan mempengaruhi besarnya tingkat Return Saham yang akan diterima oleh pemegang saham. Oleh karena itu besar kecilnya tingkat Return Saham akan mempengaruhi minat investor dalam berinvestasi.

Fenomena turunnya indeks harga saham sektoral dari industri pertambangan setidaknya dapat mengindikasikan bahwa return saham yang diperoleh investor dari industri tersebut belum optimal. Artinya realisasi return saham belum sesuai dengan return yang diharapkan oleh investor. Kondisi ini tentunya dapat mempengaruhi perilaku investor dalam menentukan preferensinya dalam berinvestasi di pasar modal. Mengingat motif utama investor berinvestasi pada perusahaan yang go public adalah mendapatkan return yang maksimal. Oleh karena itu penting bagi perusahaan untuk mampu meningkatkan nilai perusahaan sehingga terjadi peningkatan penjualan sahamnya di pasar modal. Jika diasumsikan, investor adalah seorang yang rasional, maka investor tersebut pasti akan sangat memperhatikan aspek fundamental untuk menilai ekspektasi imbal hasil atau return yang akan diperolehnya.

Menurut Arista dan Astohar (2012), return saham merupakan harga jual saham di atas harga belinya. Semakin tinggi harga jual saham di atas harga belinya, maka semakin tinggi pula return yang diperoleh investor. Apabila seorang investor menginginkan return yang tinggi maka ia harus bersedia menanggung risiko lebih tinggi, demikian 
pula sebaliknya bila menginginkan return rendah maka risiko yang akan ditanggung juga rendah.

Current ratio merupakan rasio untuk mengukur kemampuan perusahaan membayar kewajiban jangka pendek atau utang yang segera jatuh tempo pada saat ditagih secara keseluruhan. Dengan kata lain, seberapa banyak aktiva lancar yang tersedia untuk menutupi kewajiban jangka pendek yang segera jatuh tempo. Hasil penelitian yang dilakukan oleh Prihantini,R. (2009) yang menyatakan bahwa Current ratio berpengaruh Positif signifikan terhadap return saham.

Profitabilitas dalam penelitian ini akan diukur dengan Return On Equity (ROE) dan Net Profit Margin. Return On Equity merupakan perbandingan antara laba bersih dengan modal inti perusahaan. Rasio ini menunjukkan tingkat persentase yang dapat dihasilkan. Return On Equity sangat penting bagi para pemegang saham dan calon investor, karena Return On Equity yang tinggi berarti para pemegang saham akan memperoleh dividen yang tinggi pula dan kenaikan Return On Equity akan menyebabkan kenaikan harga saham. Hasil penelitian yang dilakukan oleh Pratama dan Agus (2014), Devi dan Badjra (2014), Ratih et al. (2013) dan Hutami (2012) menemukan hasil bahwa Return On Equity berpengaruh positif dan signifikan terhadap harga saham.

Net Profit Margin merupakan rasio antara laba bersih setelah pajak (net income after tax) terhadap total penjualan (sales). Rasio ini mengukur kemampuan perusahaan menghasilkan pendapatan bersihnya terhadap total penjualan yang dicapai oleh perusahaan. Jadi kinerja keuangan perusahaan dalam menghasilkan laba bersih atas penjualan semakin meningkat maka hal ini akan berdampak pada meningkatnya pendapatan yang akan diterima oleh para pemegang saham. Net profit margin semakin meningkat menggambarkan kinerja perusahaan yang semakin baik dan keuntungan yang diperoleh pemegang saham akan meningkat pula.

Firm size adalah ukuran besar kecilnya suatu perusahaan. firm size merupakan ukuran besar kecilnya perusahaan yang diukur melalui logaritma natural dari total aset (Ln total asset). Total aset dijadikan sebagai indikator ukuran perusahaan karena sifatnya jangka panjang dibandingkan dengan penjualan. Penelitian yang dilakukan oleh Sugiarto (2011) dan Purwaningrat (2014), hasil penelitiannya membuktikan bahwa firm size memiliki hubungan yang positif signifikan terhadap return saham. Penelitian yang dilakukan Adiwiratama (2012), hasil penelitiannya membuktikan ukuran perusahaan berpengaruh positif terhadap return saham. 


\section{METODE PENELITIAN}

Penelitian yang digunakan dalam penelitian ini adalah penelitian Asosiatif. Penelitian Asosiatif merupakan penelitian yang bertujuan untuk mengetahui hubungan dua variabel atau lebih (Sugiyono, 2014).

Populasi adalah wilayah generalisasi yang terdiri atas: obyek atau subyek yang mempunyai kualitas dan karakteristik tertentu yang ditetapkan oleh peneliti untuk dipelajari dan kemudian ditarik kesimpulannya. Populasi dalam penelitian ini adalah perusahaan pertambangan yang terdaftar di Bursa Efek Indonesia tahun 20102017.

Sampel adalah bagian dari jumlah dan karakteristik yang dimiliki oleh populasi tersebut. Metode yang digunakan dalam penelitian ini untuk penarikan jumlah sampel adalah menggunkan metode purposive sampling, dimana kriteria di tentukan. Sehingga Perusahaan yang memenuhi kriteria untuk dijadikan sampel sebanyak 17 perusahaan.

Jenis data yang digunakan dalam penelitian ini adalah data kuantitatif, yakni data yang berwujud angka angka. Sumber data sekunder dari penelitian ini adalah laporan keuangan perusahaan. Data sekunder ini diperoleh dari website resmi Bursa Efek Indonesia yaitu www.idx.co.id.

\section{PEMBAHASAN}

\section{A. Pengaruh Curent Ratio Terhadap Return Saham}

Hasil pengujian hipotesis secara parsial (uji t) menunjukkan bahwa variabel curent ratio berpengaruh negatif dan tidak signifikan terhadap return saham. Semakin baik curent ratio, maka semakin memburuknya likuiditas suatu perusahaan. Semakin tinggi curent ratio perusahaan, semakin rendah pula return saham yang diberikan kepada perusahaan tersebut. Nilai koefisien curent ratio menunjukan nilai yang negatif dan tidak signifikan ini sejalan dengan penelitian yang dilakukan oleh Athariq (2004) dan Raharja et al. (2008), yang menyatakan bahwa curent ratio berpengaruh negatif dan tidak signifikan terhadap return saham.

Namun hal ini tidak sejalan dengan penelitian yang dilakukan oleh Umam (2016), yang menyatakan bahwa curent ratio berpengaruh positif terhadap return saham. Hal ini menunjukkan bahwa informasi curent ratio tidak mampu memberikan sinyal bagi investor dalam mengestimasi return saham yang akan diperoleh. Pasar tidak merespon likuiditas (curent ratio) sebagai informasi yang bisa merubah keyakinan mereka, sehingga tidak mempengaruhi return saham. 


\section{B. Pengaruh Return on Equity terhadap Return Saham}

Hasil pengujian hipotesis secara parsial (uji t) menunjukkan bahwa variabel return on equityberpengaruh positif dan tidak signifikan terhadap return saham. Nilai koefisien return on equitymenunjukan nilai yang positif dan tidak signifikan ini sejalan dengan penelitian yang dilakukan oleh Agan (2011), Parwati dan Sudiartha (2016) yang menyatakan bahwa return on equity berpengaruh positif dan signifikan terhadap return saham. Hal ini menerangkan bahwa bertambahnya return on equity akan meningkatkan return saham. Dapat disimpulkan kemampuan perusahaan memperoleh laba tidak diragukan oleh investor dalam mengambil keputusan.

Namun tidak sejalan dengan penelitian yang dilakukan oleh Uuyol dan Akbas (2014), Anwar (2016) yang menyatakan bahwa terdapat pengaruh yang negatif dan terhadap return saham. Tinggi rendahnya return on equity tidak akan mempengaruhi investor dalam pengambilan keputusan investasinya, karena apabila perusahaan mampu mengelola modalnya dengan baik maka akan mampu menghasilkan profit. Maka tidak semua perusahaan yang modalnya menurun akan berpengaruh pada return saham perusahaan.

\section{Pengaruh Net Profit Margin terhadap Return Saham}

Hasil pengujian hipotesis secara parsial (uji t) menunjukkan bahwa variabel net profit margin berpengaruh negatif dan tidak signifikan terhadap return saham. Nilai koefisien net profit margin menunjukan nilai yang negatif dan tidak signifikan ini sejalan dengan penelitian yang dilakukan oleh Anwar (2016), Faried (2008) yang menyatakan bahwa net profit margin berpengaruh negatif dan tidak signifikan terhadap return saham. Semakin tinggi rasio net profit margin berarti laba yang dihasilkan oleh perusahaan juga semakin kecil maka tidak menarikminat investor untuk melakukan transaksi dengan perusahaan yang bersangkutan. Hal ini bertentangan dengan teori yang menyatakan jika kemampuan emiten dalam menghasilkan laba semakin besar maka harga saham perusahaan di pasar modal juga akan mengalami peningkatan, sehingga net profit margin berpengaruh positif terhadap return saham.

Namun, tidak sejalan dengan penelitian yang dilakukan oleh Anam (2002), yang menyatakan bahwa terdapat pengaruh yang positif terhadap return saham. Nilai net profit margin yang semakin tingggi akan memberikan kontribusi terhadapreturn saham yang semakin tinggi. 


\section{Pengaruh Firm Size Terhadap Return Saham}

Hasil pengujian hipotesis secara parsial (uji t) menunjukkan bahwa variabel firm size berpengaruh negatif dan signifikan terhadap return saham. Semakin besar total asset dalam firm size yang dimiliki perusahaan menunjukan semakin rendah kemampuan perusahaan dalam mendanai investasi-investasi yang dimiliki oleh perusahaan dan kemampuan perusahaan dalam mendanai aktifitas operasionalnya rendah, sehingga dengan hal ini menutup kemungkinan perusahaan tidak dapat memperluas pangsa pasar dan menurunkan keuntungan perusahaan, sehingga menutup kemungkinan untuk memperluas earnings dan dividen di masa mendatang yang semakin menurun. Maka, semakin besar total asset dalam firm size maka semakin kecil nilai return saham. Penelitian ini sejalan dengan penelitian yang dilakukan oleh Uuyol dan Akbas (2014) dan Umam (2016) yang menunjukan bahwa total asset mempunyai pengaruh negatif dan signifikan terhadap return saham.

Menurut Umam (2016), variabel firm size berpengaruh negatif terhadap return saham hal ini disebabkan karena emiten yang memiliki total aktiva besar belum menunjukkan bahwa perusahaan tersebut telah mencapai tahap kedewasaan di mana dalam tahap ini arus kas perusahaan sudah positif dan dianggap memiliki prospek yang baik dalam jangka waktu yang relatif lama. Selain itu juga total asset yang besar belum mencerminkan bahwa emiten relatif lebih stabil dan lebih mampu menghasilkan laba dibanding emiten dengan total asset yang kecil.

Namun hal ini tidak sejalan dengan penelitian yang dilakukan oleh Evans et al. (2014) yang menunjukan bahwa total asset mempunyai pengaruh positif dan signifikan terhadap return saham.

Semakin besar total asset dalam firm size maka semakin besar nilai return saham.

\section{KESIMPULAN}

1. Variabel curent ratio berpengaruh negatif dan tidak signifikan terhadap variabel return saham.

2. Variabel return on equity berpengaruh positif dan tidak signifikan terhadap variabel return saham.

3. Variabel net profit margin berpengaruh negatif dan tidak signifikan terhadap variabel return saham.

4. Variabel firm size berpengaruh negatif dansignifikan terhadap variabel return saham. 
5. Variabel curent ratio, return on equity, net profit margin, dan firm size secara simultan berpengaruh signifikan terhadap variabel return saham.

\section{Saran}

1. Bagi Manajer Keuangan Perusahaan dapat menentukan kebijakan peningkatan net profit margin (NPM) untuk menarik meningkatkan kesejahteraan bagi investor dan keuntungan perusahaan dari hasil dan pembahasaan penelitian ini sehingga investor pun dapat menetapkan keputusan investasi yang tepat.

2. Sebagai investor atau calon investor harus lebih teliti dan menguasai seperti apa perusahaan yang akan dijadikan tujuan investasi secara fundamental dan dilihat dari faktor makronya (risiko sistematis).

3. Faktor-faktor non keuangan merupakan faktor yang tidak kalah penting dipertimbangkan sebelum mengambil keputusan untuk berinvestasi khususnya bagi investor ataupun calon investor. Bagi perusahaan, untuk mempertahankan keberlangsungan dan kesinambungan melalui pertumbuhan berkelanjutan, sangat baik apabila senantiasa memperhatikan bukan saja faktor keuangan saja, akan tetapi faktor-faktor non keuangan sepeti good corporate governance (GCG), intellectual capital.

4. Untuk penelitian selanjutnya dapat menggunakan variabel tambahan lainnya seperti biaya operasional terhadap pendapatan operasional (BOPO) sehingga hasil penelitian lebih mampu untuk memprediksi return saham (RS) dengan lebih tepat dan akurat.

5. Peneliti selanjutnya diharapkan dapat meneliti kembali return saham(RS) sebagai variabel intervening, yang adalah sebagai variabel interaksi dengan mengalikan variabel interaksi dengan variabel independen (X) karena dapat dijadikan sebagai pembanding dan pendukung hasil yang diperoleh. 


\section{DAFTAR PUSTAKA}

Adiwiratama, Jundan. (2012). Pengaruh Informasi Laba, Arus Kas Dan Sizeperusahaan Terhadap Returnsaham (Studi Empiris Pada Perusahaan Manufaktur Yang Terdaftar Di BEI). Jurnal Ilmiah Akuntansi dan Humanika.

Agung, Sugiarto. (2011). Analisa Pengaruh Beta, Size Perusahaan, Der Dan Pbv Ratio Terhadap Return Saham, Jurnal Dhinamika Akuntansi.

Arista dan Astohar. (2012). Analisis Faktor-Faktor Yang Mempengaruhi Return Saham (Kasus Pada Perusahaan Manufaktur Yang Go Public Di BEI Periode Tahun 20052009). Jurnal Ilmu Manajemen dan Akuntansi Terapan, 2012.

Anwar, M. (2016). Impact Of Firms Performance On Stock Returns (Evidenve From Listedcompaniesof Ftse-100 Index London, UK. Journal of Management and Business.

Ananta, Agan. (2011). Pengaruh Economic Value Added, Return On Asset, dan Return On Equity Terhadap Return Saham pada perusahaan Food and Beverages yang Listing di BEI Periode 2007-2009. Skripsi Malang:FE-UM.

Athariq. (2004). Pengaruh Rasio Keuangan Terhadap Harga Saham Pada Perusahaan Manufaktur di Bursa Efek Indonesia, Medan: Universitas Sumatera Utara.

Bukhori, Iqbal, Raharja. (2008). Pengaruh Good Corporate Governance dan Ukuran Perusahaan terhadap Kinerja Perusahaan, Semarang: Diponegoro Journal of Accounting.

Basuki, Agus Trian Prawoto, Nano. (2016). Analisis Regresi Dalam Penelitian Ekonomi \&Bisnis : Dilengkapi Aplikasi SPSS \& EVIEWS, Depok : PT Raja grafindo Persada.

Brigham E. F dan J. F. Houston. ( 2006). Dasar-dasar Manajemen Keuangan, Buku 1, Edisi 10, Terjemahan Ali Akbar Yulianto. Jakarta: Salemba Empat.

Murhadi, Werner R. (2013). Analisis Laporan Keuangan, Proyeksi dan Valuasi Saham, Jakarta: Salemba Empat.

Nadiyah, Farah dan Suryono, Bambang. (2017). Pengaruh Kinerja Keuangan Dan Ukuran Perusahaan Terhadap Return Saham. Jurnal Ilmu dan Riset Akuntansi, 6 (9). ISSN:24600585.

Prihantini, Ratna. (2009). Analisis Pengaruh Inflasi, Nilai tukar, ROA, DER, CR terhadap Return Saham (Studi Kasus Saham Industri Real Estate and Property yang terdaftar di Bursa Efek Indonesia periode 2003-2006). 
Pratama, dan Agus. (2014). Pengaruh Current Ratio, Debt To Equity Ratio, Return On Equity, Net Profit Margindan Earning Per Share Terhadap Harga Saham (Studi Kasus Pada Perusahaan Manufaktur Yang Terdaftar Di Bursa Efek Indonesia Periode 2008-2011. Jurnal Akuntansi, 6(2). Juni 2014.

Parwati, R. R., dan Sudiartha, G. M. (2016). Pengaruh Profitabilitas, Leverage, Likuiditas, Dan Penilaian Pasar Terhadap Return Saham Perusahaan Manufaktur. Journal Economics and Bussiness, 385-413.

Purwaningrat, Atim. (2014). Pengaruh Perubahan Earning Per Share, Debt to Equity Ratio dan Ukurani Perusahaan Terhadapi Return Saham Perusahaan yang Tercatat di BEI Periode 2011-2013. Skripsi Universitas Udayan.

Putra, Ferdinan Eka, dan Kindangen, Paulus.(2016).Pengaruh ROA, NPM, dan EPS Terhadap Return Saham Perusahaan Makanan dan Minuman yang Terdaftar di BEI Periode 20102014.(4).(4).

Rahman Faried, Asbi. (2008). Pengaruh Faktor Fundamental dan Kapitalisasi Pasar terhadap Return Saham Perusahaan Manufaktur di Bursa Efek Indonesia Periode 2002-2006. Universitas Diponegoro.

Ratih, Dorothea, Aprianti E.P, danSaryadi. (2013). Pengaruh EPS, PER, DER, ROE Terhadap Harga Saham Pada Perusahaan Sektor Pertambangan Yang Terdaftar Di Bursa Efek Indonesia (BEI) Tahun 2010 -2012. Jurnal Sosial dan Politik Universitas di Ponegoro.

Rohmah, Latifur. (2012). Pengaruh Price Earning Ratio dan Earning Per Share Terhadap Return Saham. Skripsi Institut Agama Islam Negeri Walisongo.

Savitri Devi dan Bagus Badjra. 2014. Pengaruh ROE, NPM, Leverage Dan Nilai Pasar Terhadap Harga Saham. E-Jurnal Manajemen Universitas Udayana.

Setiyono, Erik dan Lailatul Amanah. (2016). Pengaruh Kinerja Keuangan Dan Ukuran Perusahaan Terhadap Return Saham, Jurnal Ilmu dan Riset Akuntansi.

Suwito, Edy dan Arleen Herawaty. (2005). Analisis Pengaruh Karakteristik Perusahaan Terhadap Tindakan Perataan Laba Yang Dilakukan Oleh Perusahaan Yang Terdaftar Di Bursa Efek Jakarta. Simposium Nasional Akuntansi, 8. Solo. 15-16 September. 
Susilowati, Yeye dan Turyanto, Tri. (2011). Reaksi Signal Rasio Profitabilitas Dan Rasio Solvabilitas Terhadap Return Perusahaan. Jurnal Dinamika Keuangan dan Perbankan. www.idx.co.id. 